\title{
Kangaroo IGF-II is structurally and functionally similar to the human $\left[\operatorname{Ser}^{29}\right]$-IGF-II variant
}

\author{
C A Yandell ${ }^{1,3}$, G L Francis ${ }^{1,2}$, J F Wheldrake ${ }^{1,3}$ and Z Upton ${ }^{1,2}$ \\ ${ }^{1}$ Cooperative Research Centre for Tissue Growth and Repair, PO Box 10065, Adelaide BC, 5000, South Australia, Australia \\ ${ }^{2} \mathrm{CSIRO}$, Human Nutrition, Kintore Avenue, Adelaide, 5000, South Australia, Australia \\ ${ }^{3}$ Department of Biological Sciences, Flinders University of South Australia, GPO 2100, Adelaide, 5001, South Australia, Australia \\ (Requests for offprints should be addressed to C Yandell at Cooperative Research Centre for Tissue Growth and Repair, PO Box 10065, Adelaide BC, 5000, \\ South Australia, Australia)
}

\begin{abstract}
Kangaroo IGF-II has been purified from western grey kangaroo (Macropus fuliginosus) serum and characterised in a number of in vitro assays. In addition, the complete cDNA sequence of mature IGF-II has been obtained by reverse-transcription polymerase chain reaction. Comparison of the kangaroo IGF-II cDNA sequence with known IGF-II sequences from other species revealed that it is very similar to the human variant, $\left[\mathrm{Ser}^{29}\right]$-hIGF-II. Both the variant and kangaroo IGF-II contain an insert of nine nucleotides that encode the amino acids Leu-Pro-Gly at the junction of the $\mathrm{B}$ and $\mathrm{C}$ domains of the mature protein. The deduced kangaroo IGF-II protein sequence also contains three other amino acid changes that are not observed in human IGF-II. These amino acid differences share similarities with the changes described in many of the IGF-IIs reported for non-mammalian species. Characterisation of human IGF-II, kangaroo IGF-II, chicken IGF-II and [ $\left.\mathrm{Ser}^{29}\right]$-hIGF-II in a number of in vitro
\end{abstract}

assays revealed that all four proteins are functionally very similar. No significant differences were observed in the ability of the IGF-IIs to bind to the bovine IGF-II/cationindependent mannose 6-phosphate receptor or to stimulate protein synthesis in rat L6 myoblasts. However, differences were observed in their abilities to bind to IGF-binding proteins (IGFBPs) present in human serum. Kangaroo, chicken and $\left[\mathrm{Ser}^{29}\right]$-hIGF-II had lower apparent affinities for human IGFBPs than did human IGF-II. Thus, it appears that the major circulating form of IGF-II in the kangaroo and a minor form of IGF-II found in human serum are structurally and functionally very similar. This suggests that the splice site that generates both the variant and major form of human IGF-II must have evolved after the divergence of marsupials from placental mammals.

Journal of Endocrinology (1999) 161, 445-453

\section{Introduction}

The insulin-like growth factors (IGF-I and IGF-II) are mitogenic proteins that play an important role in the regulation of growth and development in vertebrates. The mature proteins, consisting of four domains $(B, C, A$ and D) are structurally related to proinsulin and have been highly conserved throughout vertebrate evolution (for review see Duguay et al. 1995, 1996).

While IGF-I has an important role in mediating many of the effects of growth hormone postnatally, IGF-II appears to be important during embryonic development. Transgenic mice in which the IGF-II gene has been disrupted show impaired embryonic growth, attaining only $60 \%$ of the body weight of their normal littermates at birth (DeChiara et al. 1990). There is also considerable evidence that suggests that IGF-II plays a crucial role in the development of the placenta (Han et al. 1996, Reynolds et al. 1997). Indeed, developmental analysis of the growth kinetics in mouse embryos carrying null mutations of IGF and IGF receptor genes, alone or in combination, suggested that the effect of IGF-II on placental growth is mediated by another receptor, originally termed receptor X (Wang et al. 1994). A more recent study has confirmed that placental growth is compromised only in mutants lacking IGF-II and that IGF-II acts via an unknown placenta-specific receptor which is distinct from the type-1 IGF and insulin receptors (Louvi et al. 1997).

The IGF-II gene is a single copy gene that is expressed as a family of RNA transcripts (Brissenden et al. 1984, Tricoli et al. 1984, Jansen et al. 1985). The heterogeneity of these transcripts originates from the use of multiple promoters, alternative splicing and differential use of polyadenylation sites. While the majority of IGF-II exists as the mature form of $7 \cdot 5 \mathrm{kDa}$, high molecular weight (MW) isoforms of IGF-II have been detected in human serum (Zumstein et al. 1985, Gowan et al. 1987), 
cerebrospinal fluid (Haselbacher \& Humbel 1982) and malignant tissue extracts (Daughaday et al. 1988, Daughaday \& Kapadia 1989). Variant forms of IGF-II have also been identified in human serum (Hampton et al. 1989, Straczek et al. 1990, Van den Brande et al. 1990) and placental tissue (De Ceuninck et al. 1995b).

IGF-II binds with high affinity to two very different membrane-bound receptors: (i) the type 1 IGF receptor, which contains intrinsic tyrosine kinase activity and is activated upon ligand binding, and (ii) the type 2 IGF receptor, a multifunctional receptor that has also been identified as the cation-independent mannose 6-phosphate receptor (CI-MPR). The full physiological role of IGF-II binding to the CI-MPR in particular is presently unclear and somewhat controversial. Interestingly, the avian and amphibian CI-MPRs lack the binding site for IGF-II but are able to bind mannose 6-phosphate-bearing ligands (Canfield \& Kornfeld 1989, Clairmont \& Czech 1989). However, the CI-MPR from the opossum, a species that recently diverged from placental mammals, can bind IGF-II, albeit with a 75-fold lower affinity than the bovine receptor (Dahms et al. 1993). Thus, the IGF-II binding property of the CI-MPR appears to be have been acquired later in vertebrate evolution and may be limited to mammals.

While our knowledge of IGF structure and function in mammalian species has been well defined, the evolution of the individual components of the IGF systems in other species is less well understood. For example our knowledge of the IGF system in birds (except for commercially relevant species) or indeed in any species ancestral to eutherian (placental) mammals is remarkably limited. While both are mammals, one of the key differences between metatherians (marsupials) and eutherians is the evolution of different modes of feto-maternal interactions during embryonic development. The metatherians are distinct in that, while the embryo is reliant on a yolk sac for nutrients, implantation and development of a placenta occur late in pregnancy (Renfree 1993, 1995). The embryo is born at an early stage of development and its survival is dependent on finding its way to the pouch and a mammary teat for nourishment. In eutherians on the other hand, implantation and placental invasion occur early in gestation, the embryo is born at a comparatively advanced stage of development and the young are generally quickly weaned. In the light of the convincing research that has been undertaken in eutherians pointing to a major role for IGF-II in fetal development (DeChiara et al. 1990, Wang et al. 1994) examination of the similarities, as well as differences, in these two classes of mammals may be beneficial in understanding the function of IGFs during embryogenesis. However, an important first step to this end is to gain an understanding of the basics of the IGF system in marsupials. We have previously reported the purification of IGFs from kangaroo serum and the characterisation of kangaroo IGF-I (kIGF-I) (Yandell et al. 1998). Here we report, for the first time, the complete cDNA sequence and characterisation of a marsupial IGF-II.

\section{Materials and Methods}

\section{Materials}

Kangaroo blood was collected from wild western grey kangaroos (Macropus fuliginosus) at Peterborough, South Australia, Australia. Recombinant human IGF-II (rhIGFII) and chicken IGF-II (cIGF-II) were supplied by GroPep Pty Ltd, Adelaide, South Australia, Australia. Bovine livers from freshly slaughtered cattle were obtained from Agpro Abattoir, Gepps Cross, South Australia, Australia and were snap frozen in liquid $\mathrm{N}_{2}$ before being stored at $-80^{\circ} \mathrm{C}$. Blood collected from female nonpregnant tammar wallabies (M. engenii) was kindly donated by Professor Russell Baudinette, University of Adelaide, Department of Zoology, South Australia, Australia. Radioiodinated rhIGF-II was prepared to specific activities between 30 and $60 \mu \mathrm{Ci} / \mu \mathrm{g}$ with chloramine- $\mathrm{T}$ and separated from reaction components by chromatography on a Sephadex G50 column as previously described (Francis et al. 1989). Recombinant $\left[\mathrm{Ser}^{29}\right]-\mathrm{hIGF}-\mathrm{II}$ was a generous gift from Dr C Lüthi, University of Zurich, Zurich, Switzerland. The mouse monoclonal antibody raised against rat IGF-II was generously provided by $\operatorname{Dr} K$ Nishikawa, Kanazawa Medical University, Uchinada, Ishikawa, Japan. Sheep anti-mouse Ig was obtained from Silenus Laboratories, Hawthorn, Victoria, Australia and carrier-free $\mathrm{Na}^{125} \mathrm{I}$ was purchased from Amersham International, Amersham, Bucks, UK.

The Wizard PCR DNA Purification System was purchased from Promega, Madison, WI, USA while the RNeasy Mini Kit was purchased from Qiagen $\mathrm{GmbH}$, Hilden, Germany. ELONGASE enzyme mix, $10 \mathrm{mM}$ dNTP Mix, oligo(dT) and Superscript II RT were purchased from Gibco-BRL, Life Technologies, Eggenstein, Germany. Specific oligonucleotide primers as described below were synthesised by Gibco-BRL, Life Technologies. The Expand High Fidelity PCR System was obtained from Boehringer Mannheim, Castle Hill, New South Wales, Australia and the ThermoSequenase sequencing kit was obtained from Amersham Life Sciences, Cleveland, OH, USA.

\section{Methods}

IGF-II purification and characterisation kIGF-II was purified from western grey kangaroo serum as described by Yandell et al. (1998). Purity was assessed by $\mathrm{N}$-terminal protein sequencing and quantitation was performed as described by Upton et al. (1995) using the calculated absorption coefficient of $31.69 \mathrm{~g} / 1$ per $\mathrm{cm}$ at $214 \mathrm{~nm}$.

kIGF-II was characterised in a number of in vitro assays where it was compared with hIGF-II, cIGF-II and the 
human variant, $\left[\mathrm{Ser}^{29}\right]$-hIGF-II. Before analysis the samples were dried under vacuum, dissolved in $\mathrm{HCl}$ $(10 \mathrm{mM})$ and resuspended in the appropriate assay buffer.

IGF-II RIAs were carried out as described in Kita et al. (1996) using ${ }^{125}$ I-hIGF-II as the radioligand and a monoclonal antibody raised against rat IGF-II. The amount of specific antiserum used was adjusted to produce 30-40\% tracer binding. Non-specific binding was not subtracted and binding was expressed as the percentage of the control with no IGF-II added.

Protein synthesis was determined using confluent cultures of rat L6 myoblasts and was measured as the incorporation of $\left[{ }^{3} \mathrm{H}\right]$ leucine into total cell protein over a $16 \mathrm{~h}$ incubation period as previously described (Ballard et al. 1986). Responses are expressed as the percentage stimulation above that of the control with no added IGF-II.

Binding of IGF-II to purified bovine IGF-II (bIGF-II)/ CI-MPR was measured as previously described (Scott \& Baxter 1987). The IGF-II/CI-MPR was purified from bovine liver by phosphomannan-Sepharose affinity chromatography as described in Dahms et al. (1993). Competition for binding with ${ }^{125}$ I-hIGF-II to bIGF-II/ CI-MPR was again expressed as a percentage of the control with no added IGF-II.

Binding of IGF-II to IGF-binding proteins (IGFBPs) in human or tammar wallaby serum was carried out as described in Szabo et al. (1988). Briefly, radioligand and unlabelled IGF-II were added to $30 \mu \mathrm{l}$ serum and incubated for $16 \mathrm{~h}$ at $4{ }^{\circ} \mathrm{C}$. After incubation, bound radioligand was separated from free radioligand by the addition of a $0 \cdot 5 \%(\mathrm{w} / \mathrm{v})$ charcoal suspension for $30 \mathrm{~min}$. The amount of free radioligand was determined by counting the radioactivity in the pellet after centrifugation. The results are expressed as a percentage of the control with no added IGF-II.

All concentrations of IGF-II were assayed in triplicate, with most experiments repeated at least three times as indicated in the figure legends. The $\mathrm{IC}_{50}$ values for all assays were determined using TableCurve (Jandel Scientific, San Rafael, CA, USA). Statistical analysis was performed using repeated-measures ANOVA. A $P$ value $<0.05$ was considered an indication of a significant difference between means.

Reverse transcription-polymerase chain reaction (RT-PCR) and sequence analysis The cDNA sequence for kIGF-II was obtained using mRNA extracted from kangaroo liver, followed by RT-PCR. RNA was extracted using the RNeasy Mini Kit. The quality of the RNA was assessed by ethidium bromide staining after agarose gel electrophoresis. First-strand cDNA was synthesised from total RNA using $0.5 \mu \mathrm{g}$ oligo(dT) primer and 200 U Superscript II RT enzyme in a total volume of $20 \mu \mathrm{l}$ according to the manufacturer's protocols.
Primer design and amplification Amplification of kIGF-II was performed using non-degenerate oligonucleotide primers. Primer IGF2-1 was based on the partial cDNA sequence of tammar wallaby IGF-II (S Wilcox, Royal Children's Hospital, Melbourne, Victoria, Australia, personal communication), while primer IGF2-2 was designed from the cDNA sequence of the $\mathrm{E}$ domain of human IGF-II. The primer pair 5' CTGTTATCACT CAC 3' (IGF2-1) and 5' AATCAGGGGACGGTG 3' (IGF2-2) amplify a fragment of approximately $489 \mathrm{bp}$ that includes portions of the prepro-IGF-II molecule as well as the entire mature protein sequence. The PCR was carried out in a total volume of $50 \mu \mathrm{l}$ containing $60 \mathrm{mM}$ Tris-SO (pH 9.1), $18 \mathrm{mM}\left(\mathrm{NH}_{4}\right)_{2} \mathrm{SO}_{4}, 1.5 \mathrm{mM} \mathrm{MgSO}{ }_{4}, 0 \cdot 2 \mathrm{mM}$ dNTP, 0.5 U ELONGASE, $200 \mathrm{ng}$ oligonucleotide primers and $2.5 \mu \mathrm{l}$ cDNA template. After denaturation at $94{ }^{\circ} \mathrm{C}$ for $3 \mathrm{~min}$, the PCR reaction proceeded for 40 cycles of $1 \mathrm{~min}$ at $94{ }^{\circ} \mathrm{C}$ (denaturation), $1 \mathrm{~min}$ at $50{ }^{\circ} \mathrm{C}$ (annealing) and $1 \mathrm{~min}$ at $68^{\circ} \mathrm{C}$ (extension).

The PCR product was purified by the Wizard PCR DNA Purification System prior to sequencing. Sequencing was performed using a radiolabelled terminator cycle sequencing kit, ThermoSequenase, with the PCR product sequenced in both the forward and reverse directions. Sequencing was performed on products from two independent RT-PCRs.

\section{Results}

\section{Purification and $c D N A$ sequencing of KIGF-II}

IGF-II was purified from western grey kangaroo serum as previously described (Yandell et al. 1998). A yield of $106 \mu \mathrm{g}$ IGF-II from 71 of serum was obtained and was determined by $\mathrm{N}$-terminal protein sequencing to be $95 \%$ pure. Electrospray mass spectroscopy revealed that kIGF-II isolated from serum had a molecular mass of $2921 \mathrm{Da}$, approximately $450 \mathrm{Da}$ larger than that reported for hIGF-II (Rinderknecht \& Humbel 1978). Previous attempts at determining the sequence of kIGF-II by Edman degradation $\mathrm{N}$-terminal protein sequencing indicated that the A, B and D domains were highly conserved (Yandell et al. 1998). Hence, it was reasoned that the changes accounting for the mass differences between kIGF-II and hIGF-II must lie within the C domain. As endo-proteinase digestion and $\mathrm{N}$-terminal protein sequencing require the use of relatively large amounts of protein, RT-PCR was used to obtain the cDNA sequence of kIGF-II.

RT-PCR primers were designed using the known sequence of the tammar wallaby (S Wilcox, personal communication) prepro-IGF-II signal peptide and a conserved region of the $\mathrm{E}$ domain from mammalian species. This primer set amplified a band of approximately $500 \mathrm{bp}$ and subsequent sequencing of this product revealed it to be IGF-II (Fig. 1a). The theoretical molecular mass 
(a)

\begin{tabular}{|c|c|c|c|c|c|c|c|c|c|c|c|}
\hline Ala & TYI & Arg & Pro & ser & GIu & Thr & Leu & Cys & GIY & GIY & 01 \\
\hline ' GCT & TAT & $\mathrm{CGG}$ & $\mathrm{CCC}$ & $\mathrm{AGT}$ & $G A G$ & $A C C$ & $\mathrm{CTT}$ & TGT & GGT & $G G G$ & \\
\hline Leu & Val & $\mathbf{A s p}$ & Thr & Leu & GIn & Phe & Val & $C_{Y S}$ & G1Y & Asp & \\
\hline $\mathrm{CTG}$ & GTA & $\mathrm{GAC}$ & $\mathrm{ACT}$ & $\mathrm{CTC}$ & $C A G$ & $\mathrm{TTT}$ & GTG & $\mathrm{TGT}$ & $\mathrm{GGC}$ & $\mathrm{GAC}$ & \\
\hline GIY & Phe & $T_{Y I}$ & Phe & Ser & Leu & Pro & GIY & Arg & Pro & Leu & \\
\hline $\mathrm{GGC}$ & $\mathrm{TTC}$ & $\mathrm{TAT}$ & TTC & $A G T$ & $\mathrm{CTT}$ & $\mathrm{CCT}$ & $\mathrm{GGC}$ & $A G A$ & $\mathrm{CCC}$ & $\mathrm{CTG}$ & \\
\hline Arg & Val & ser & Arg & Arg & Leu & Asn & $A \times g$ & GIY & Ile & Val & \\
\hline $\mathrm{CGC}$ & GTG & $A G C$ & CGT & $\mathrm{CGC}$ & $\mathrm{CTG}$ & $A A T$ & $\mathrm{CGC}$ & GGC & ATC & GTG & \\
\hline Glu & $\mathrm{CY}_{\mathbf{s}}$ & $C_{Y g}$ & Phe & Arg & ser & $C_{Y} \mathrm{~s}$ & Asp & Leu & A1a & Leu & \\
\hline$G A G$ & TGT & $\mathrm{TGC}$ & TTC & $\mathrm{CGC}$ & $A G C$ & TGT & GAT & $\mathrm{CTG}$ & $\mathrm{GCC}$ & $\mathrm{CTG}$ & \\
\hline & ThI & Ty & $\mathrm{Cy}^{\mathrm{s}}$ & Ala & Thr & Pro & Ala & Ly $\mathbf{s}$ & Ser & Glu & \\
\hline$G A G$ & $\mathrm{ACC}$ & $\mathrm{TAC}$ & TGT & $\mathrm{GCT}$ & $\mathrm{ACC}$ & $\mathrm{CCT}$ & $\mathrm{GCC}$ & $A A G$ & $\mathrm{TCC}$ & $G A G$ & \\
\hline
\end{tabular}

(b)

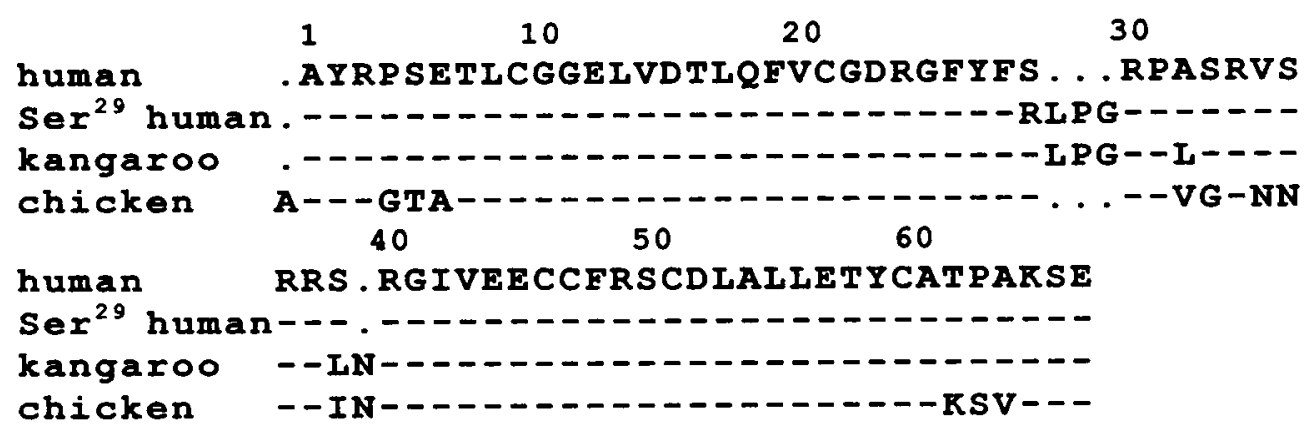

Figure 1 (a) The cDNA and deduced amino acid sequence of mature kIGF-II and (b) comparison of amino acid sequences of human, chicken, kangaroo and $\left[\mathrm{Ser}^{29}\right]$-hIGF-II. Sequences are those reported by Rinderknecht \& Humbel (1978) (human), Kallincos et al. (1990) (chicken) and Hampton et al. (1989) ([Ser $\left.{ }^{29}\right]$-hIGF-II) while the sequence for the kIGF-II is deduced from the present study and Yandell et al. (1998). Dashed lines represent identical sequence compared with hIGF-II. Periods were used to frame shift proteins for maximal alignment between sequences. Numbering is according to the human sequence.

calculated from the deduced amino acid sequence was the same as that obtained from the mass spectroscopy analysis of kIGF-II purified from serum. Comparison of the deduced amino acid sequence of kIGF-II and the hIGF-II amino acid sequence revealed that the $\mathrm{A}, \mathrm{B}$ and $\mathrm{D}$ domains are indeed highly conserved (Fig. 1b). However, the C domain of kIGF-II contains an insert of Leu-ProGly at position 30 (numbering using the human sequence), a substitution of Leu for Ala at position 32, Leu for Ser at position 39, as well as an insert of an Asn at position 40. An insertion of Leu-Pro-Gly in the C domain of IGF-II has also been described in an IGF-II variant, $\left[\mathrm{Ser}^{29}\right]$-hIGF-II, found in human serum and placental tissue (Hampton et al. 1989, DeCeuninck et al. 1995b). In addition to the tripeptide insert, the human variant has a substitution of $\mathrm{Arg}$ for $\mathrm{Ser}^{29}$. At the nucleotide level, the cDNA sequence of kIGF-II shares 100\% identity with the partial tammar wallaby IGF-II cDNA sequence and 85\% identity with $\left[\mathrm{Ser}^{29}\right]-\mathrm{hIGF}-\mathrm{II}$.
Characterisation

In order to examine if the structural differences between kIGF-II and IGF-II from other species conferred any functional differences, kIGF-II was characterised in a number of in vitro assays and compared with hIGF-II, cIGF-II and the human variant, [Ser $\left.{ }^{29}\right]$-hIGF-II. The affinity of binding to the IGF-II/CI-MPR was examined by measuring competition with ${ }^{125} \mathrm{I}-\mathrm{hIGF}-\mathrm{II}$ for binding to bIGF-II/CI-MPR purified from liver (Fig. 2). Halfmaximal competition for binding was observed at $61.5 \pm 7.9$ (mean \pm s.E.M.), $57.9 \pm 7 \cdot 9, \quad 52.3 \pm 3.8$ and $51 \cdot 4 \pm 1 \cdot 2 \mathrm{pM}$ for kIGF-II, hIGF-II, cIGF-II and [Ser ${ }^{29}$ ]hIGF-II respectively. There were no significant differences between the mean $\mathrm{IC}_{50}$ values of all four proteins $(P>0 \cdot 05)$.

The ability of the proteins to stimulate protein synthesis in rat L6 myoblasts was also examined by measuring the incorporation of $\left.{ }^{3} \mathrm{H}\right]$ leucine into total protein (Fig. 3). All IGF-IIs were found to have a similar potency with 


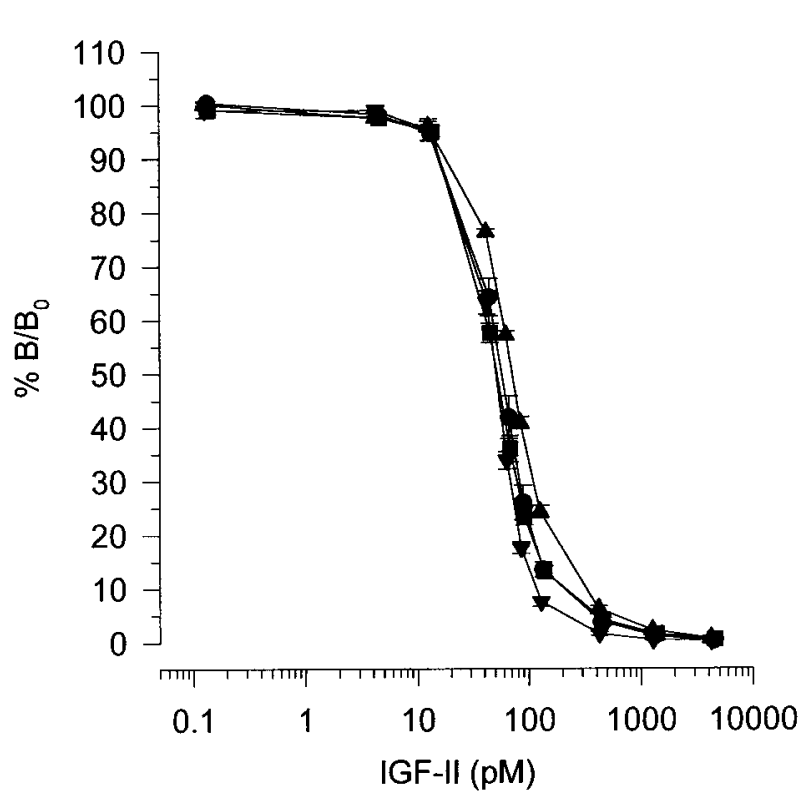

Figure 2 Competition for binding of ${ }^{125}$ I-hIGF-II to purified bIGF-II/Cl-MPR. The competing ligands were human $(\bullet)$, kangaroo $(\boldsymbol{\Delta})$, chicken $(\boldsymbol{\square})$ and $\left[\operatorname{Ser}^{29}\right]$-hIGF-II $(\boldsymbol{\nabla})$. Binding is expressed as a percentage of the binding observed in the absence of competing IGF-II. Values are means \pm S.E.M. for three separate experiments.

half-maximal effects observed at concentrations of $13 \cdot 0 \pm 1 \cdot 2,10 \cdot 3 \pm 1 \cdot 7,8 \cdot 9$ (no S.E.M. as only one experiment was performed) and $7 \cdot 8 \pm 1 \cdot 0 \mathrm{nM}$ for cIGF-II, kIGF-II, [Ser ${ }^{29}$ ]-hIGF-II and hIGF-II respectively. Again there were no significant differences between these values $(P>0 \cdot 05)$.

On the other hand, differences in the affinities of the IGF-IIs for human IGFBPs were observed in competitive binding studies using human serum (Fig. 4a). kIGF-II was the least effective $(P<0 \cdot 001)$ at competing with ${ }^{125}$ I-hIGF-II for binding to the IGFBPs in human serum. cIGF-II and [ $\left.\mathrm{Ser}^{29}\right]$-hIGF-II were also significantly less effective than hIGF-II in their ability to bind to the human IGFBPs $(P<0.05)$ in this assay. The half-maximal inhibitory concentrations observed for kIGF-II, cIGF-II, [Ser $\left.{ }^{29}\right]$-hIGF-II and hIGF-II were $5 \cdot 32 \pm 0 \cdot 25,3 \cdot 81 \pm 0 \cdot 15,3 \cdot 67 \pm 0 \cdot 13$ and $2 \cdot 89 \pm$ $0 \cdot 17 \mathrm{nM}$ respectively.

To determine if the differences detected in IGFBP affinity were due to the heterologous nature of the assay, we also tested the ability of kIGF-II and hIGF-II to compete for binding to the IGFBPs found in the serum of a marsupial, the tammar wallaby (Fig. 4b). hIGF-II and kIGF-II were similar in their ability to bind to tammar wallaby IGFBPs with half-maximal competition observed at concentrations of $7 \cdot 1$ and $7 \cdot 4 \mathrm{nM}$ respectively.

The cross-reactivity of kIGF-II in an RIA using a monoclonal antibody raised against rat IGF-II was also examined (Fig. 5). This antibody has been routinely used

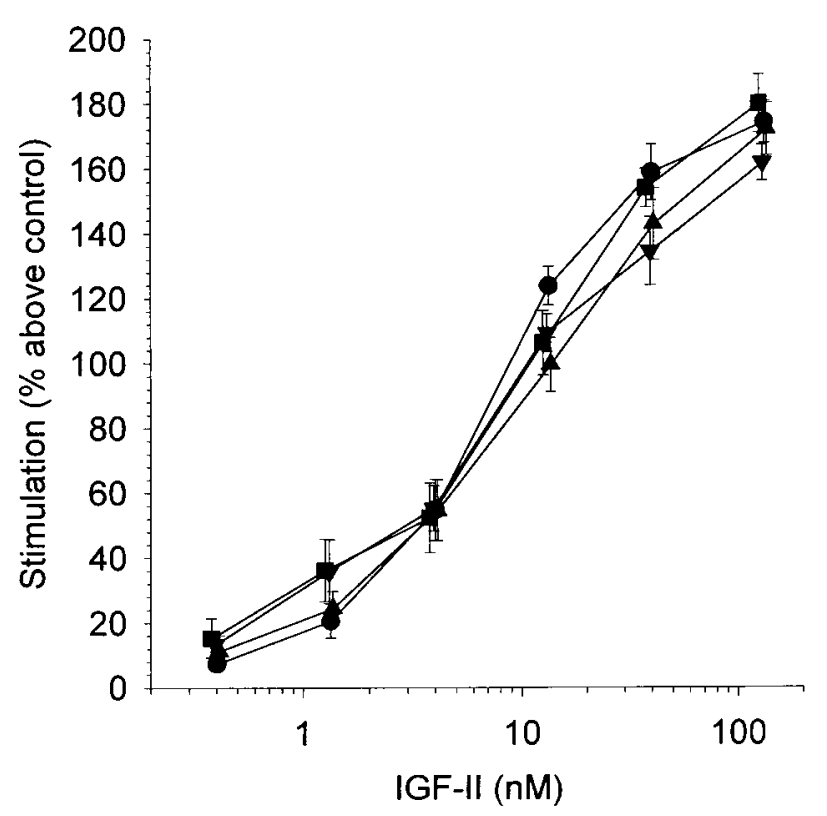

Figure 3 Dose-response curves of hIGF-II $(\bullet)$, kIGF-II ( $\mathbf{\Delta})$, clGF-II ( $\mathbf{\square})$ and $\left[\mathrm{Ser}^{29}\right]$-hIGF-II $(\boldsymbol{\nabla})$ in a rat L6 myoblast protein synthesis assay. Bioactivity is expressed as the percentage stimulation above that of cells incubated with medium alone. Values are means \pm S.E.M. for two separate experiments for human, chicken and kangaroo IGF-II. Values for $\left[\mathrm{Ser}^{29}\right]$-hIGF-II are the mean \pm S.D. of one experiment.

in our laboratory for measuring the levels of IGF-II in rat and human sera. The concentration curves obtained from serial dilutions of kIGF-II and hIGF-II were parallel. However, the concentrations required for half-maximal binding with kIGF-II and hIGF-II, $24 \cdot 4 \pm 1 \cdot 6$ and $12 \cdot 9 \pm 0 \cdot 4 \mathrm{pM}$ respectively, were significantly different $(P<0 \cdot 05)$.

\section{Discussion}

We have previously purified both IGF-I and IGF-II from western grey kangaroo serum and reported the characterisation and full sequence of IGF-I (Yandell et al. 1998). We have now obtained the complete cDNA sequence for kIGF-II and characterised the purified protein in a number of in vitro assays.

The molecular mass of the purified material as determined by electrospray mass spectrometry was $7921 \mathrm{Da}$, approximately $450 \mathrm{Da}$ larger than that reported for hIGF-II (Rinderknecht \& Humbel 1978). To confirm this result and to obtain the complete amino acid sequence we used RT-PCR of mRNA isolated from kangaroo liver to obtain the cDNA sequence of kIGF-II. The cDNA sequence of kIGF-II revealed 100\% identity with the partial IGF-II cDNA sequence obtained previously from the tammar wallaby. This finding is not unexpected as the 

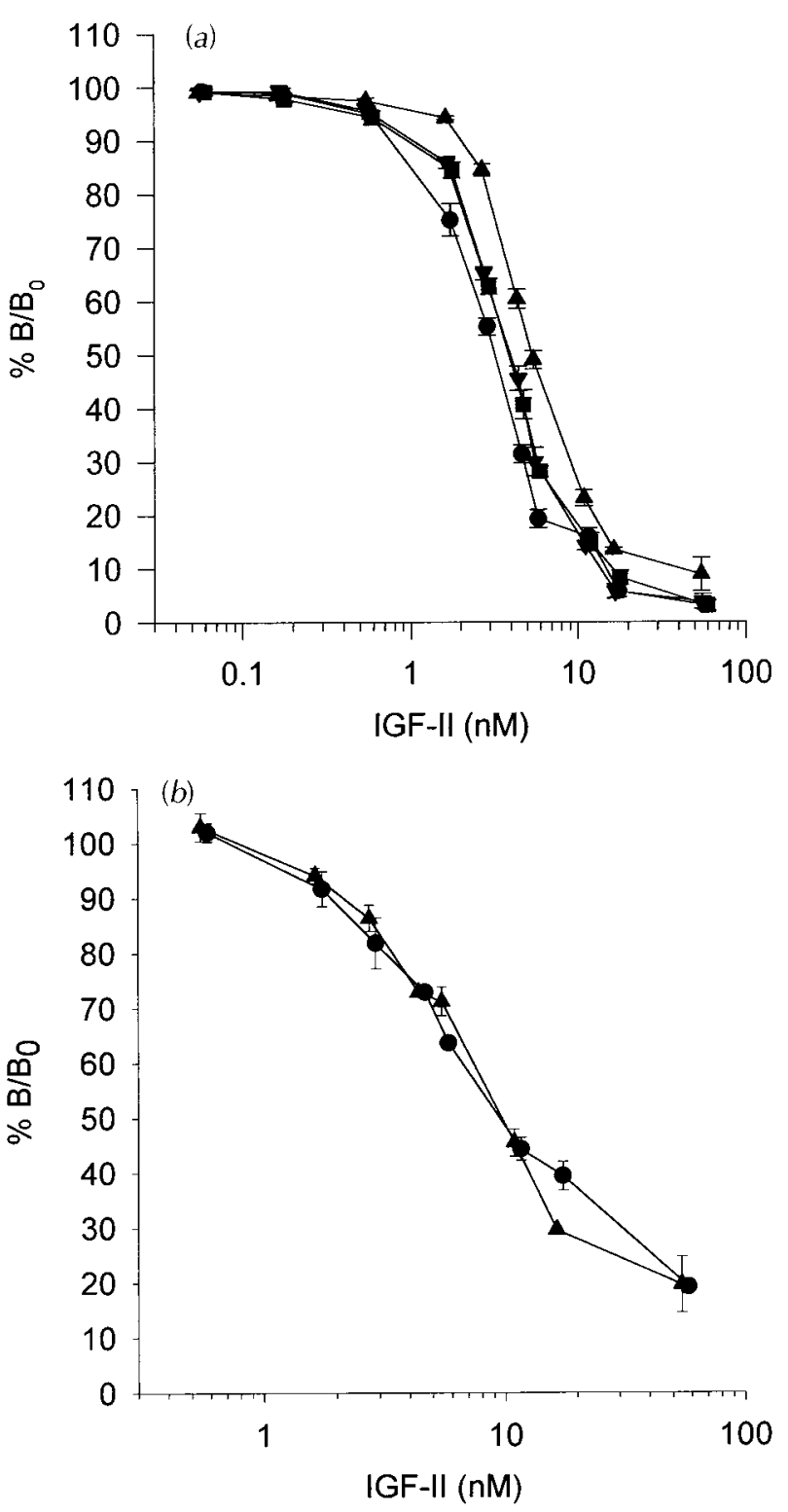

Figure 4 Competition for binding of ${ }^{125}$ I-hIGF-II to IGFBPs in (a) human serum and $(b)$ tammar wallaby serum. The competing ligands were human $(\boldsymbol{O})$, kangaroo $(\boldsymbol{\Delta})$, chicken $(\boldsymbol{\square})$ and $\left[\right.$ Ser $\left.^{29}\right]$-hIGF-II $(\boldsymbol{\nabla})$. Binding is expressed as a percentage of the binding observed in the absence of competing IGF-II. Values are means \pm S.E.M. for three separate experiments for the human serum. Values for the tammar wallaby serum are the mean \pm S.D. of one experiment.

western grey kangaroo and tammar wallaby are closely related species. Comparison of the deduced amino acid sequence with hIGF-II revealed that kIGF-II contains six amino acids that are different from the hIGF-II sequence. One major difference is that the kangaroo protein has a three amino acid insert of Leu-Pro-Gly at position 30 (numbering based on human sequence). Comparison with

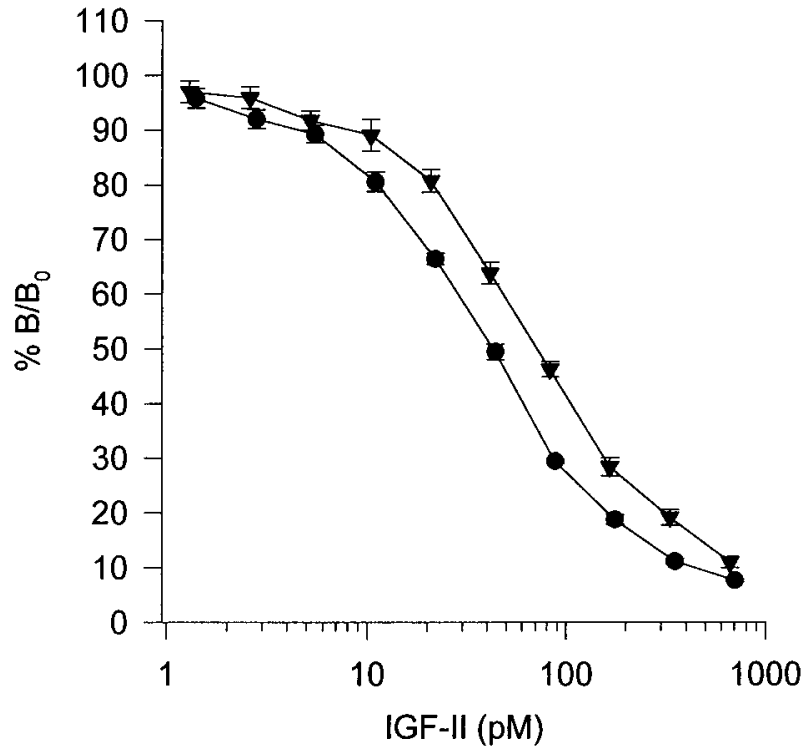

Figure 5 IGF-II RIA using antiserum raised against rat IGF-II. The radioligand was ${ }^{125} \mathrm{I}$-hIGF-II and the competing ligands were hIGF-II $(\mathbf{O})$ and $\operatorname{kIGF}-I I(\boldsymbol{\nabla})$. Values are means \pm S.E.M. for three separate experiments.

other known IGF-II sequences revealed that kIGF-II is similar to a minor IGF-II variant, $\left[\mathrm{Ser}^{29}\right]$-hIGF-II, previously described in human serum (Hampton et al. 1989, Straczek et al. 1990) and placental tissue (De Ceuninck et al. 1995b). This variant also contains an insertion of Leu-Pro-Gly at position 30 along with a substitution of Arg for Ser at position 29. The variant mRNA arises from alternative splicing of a common RNA precursor and the sequence contains a typical acceptor site $\left(5^{\prime}-\mathrm{CTTC}\right.$ CAG- $\left.3^{\prime}\right)$ in the extra nine nucleotides that encode LeuPro-Gly (Jansen et al. 1985). The A and the G nucleotides of the AGC codon for $\mathrm{Ser}^{29}$ most likely act as donor and acceptor splice sites respectively. Furthermore, nucleotide sequence analysis of the IGF-II gene indicates that there is a 1700 nucleotide intron at exactly this point (Dull et al. 1984). The kIGF-II cDNA sequence (Fig. 1a) differs slightly from the human variant cDNA sequence in this region, which suggests that alternate splicing may not occur, giving rise to only the larger mRNA transcript. Thus, we propose that the splice site that generates the major form of hIGF-II has evolved recently, occurring after the divergence of metatherians from eutherian mammals. The hypothesis that the IGF-II variant in humans arises from an ancestor gene in marsupials suggests that this variant may also be present in other mammalian species.

Surprisingly, we found no evidence for any higher MW IGF-II isoforms or variant IGF-IIs during the purification procedure. Nor did we identify any other RNA transcripts of IGF-II when cloning IGF-II from kangaroo liver. However, several variants of IGF-I were detected during 
the purification of the IGF-I from kangaroo serum (Yandell et al. 1998). The difference(s) between the variant forms and the major circulating kIGF-I were not established. In contrast, human serum contains several IGF-II variants (Hampton et al. 1989, Straczeck et al. 1990, Van den Brande et al. 1990) and higher MW isoforms of IGF-II (Zumstein et al. 1985, Gowan et al. 1987) that together comprise a minor component of total circulating IGF-II. The physiological role of both the high MW forms of IGF-II and IGF-II variants is, at present, unclear.

The deduced kIGF-II protein sequence also contains three other amino acid changes that are not observed in hIGF-II. These changes share similarities with the differences identified in many of the IGF-IIs reported for non-mammalian species. Indeed, all differences detected in the kIGF-II sequence, except the tripeptide insertion, are conservative changes arising from a one-nucleotide mutation of the cIGF-II sequence. Whether there are avian IGF-IIs which also contain an insert at the B-C hinge awaits sequencing of IGF-II cDNA or protein from other avian species.

Analysis of receptor/ligand binding using purified bIGF-II/CI-MPR indicated that kIGF-II binds to this receptor with affinity equal to all other IGF-IIs tested. This result is in agreement with the results reported by De Ceuninck et al. $(1995 a, b)$ who found that [ $\left.\mathrm{Ser}^{29}\right]$-hIGF-II had equal affinity with hIGF-II for IGF-II/CI-MPRs on ovine placental membranes and chondrocyte membranes. However, it has also been demonstrated that $\left[\mathrm{Ser}^{29}\right]-$ hIGF-II has a $10 \%$ higher affinity than IGF-II for BHK cells overexpressing the IGF-II/CI-MPR (Lüthi et al. 1992). The small differences observed between these studies may be due to the use of the different assay systems as the residues proposed to be important for IGF-II binding to this receptor, residues $48-50$ and 54-55 (Burgisser et al. 1991, Sakano et al. 1991), have been conserved in $\left[\mathrm{Ser}^{29}\right]$-hIGF-II, kIGF-II and hIGF-II.

The ability of kIGF-II, hIGF-II, cIGF-II and [Ser $\left.{ }^{29}\right]-$ hIGF-II to stimulate protein synthesis in L6 myoblasts was also examined. While there was a trend suggesting that kIGF-II was less potent (1.3-fold) than hIGF-II, this difference was not statistically significant. Nor were there any significant differences between the potencies of $\left[\mathrm{Ser}^{29}\right]$-hIGF-II, hIGF-II and cIGF-II. Previous studies report that in HIGRI cells overexpressing the type 1 IGF receptor, $\left[\mathrm{Ser}^{29}\right]$-hIGF-II was $1 \cdot 4$-fold less potent than hIGF-II at stimulating $\left[{ }^{3} \mathrm{H}\right]$ thymidine incorporation into DNA (Lüthi et al. 1992). Similarly, [Ser $\left.{ }^{29}\right]-$ hIGF-II was 2to 3 -fold less potent than hIGF-II at stimulating growth in MCF-7 cells (Hampton et al. 1989) and at stimulating sulphation in cultured chondrocytes (De Ceuninck et al. 1995a).

The B-C hinge region of IGFs is believed to be important for binding to the type 1 IGF receptor (Humbel 1990). Arguably, the three amino acid insert at this interface in both kIGF-II and [Ser $\left.{ }^{29}\right]$-hIGF-II may alter their affinities for this receptor. Indeed, $\left[\mathrm{Ser}^{29}\right]$-hIGF-II has been shown to have a lower affinity than hIGF-II for type 1 IGF receptors on human placental membranes (Hampton et al. 1989, De Ceuninck et al. 1995b), HIGRI cells overexpressing the type 1 IGF receptor (Lüthi et al. 1992) and in cultured chondrocyte membranes (De Ceuninck et al. 1995a). As the mitogenic activity of IGF-II is mediated through its interaction with this receptor this may explain the lower potency of $\left[\mathrm{Ser}^{29}\right]$-hIGF-II and kIGF-II.

There were significant differences in the ability of the four IGF-IIs to compete with ${ }^{125}$ I-hIGF-II for binding to the IGFBPs present in human serum. In order of increasing affinity they were kIGF-II $<$ CIGF-II $=\left[\mathrm{Ser}^{29}\right]$ hIGF-II $<$ hIGF-II. This finding contrasts with that reported by Lüthi et al. (1992), who found that the ability of $\left[\mathrm{Ser}^{29}\right]$-hIGF-II to compete for binding with ${ }^{125} \mathrm{I}-$ hIGF-II to recombinant IGFBP-3 was $171 \%$ of that observed for hIGF-II. As IGF-II and IGFBP-3 in serum are likely to be found in a ternary complex with the acid-labile subunit this may explain the differences in apparent affinities between recombinant IGFBP-3 and IGFBPs in serum. Likewise, the differences between these two studies may also reflect the differences in the affinities of the IGF-IIs for the other IGFBPs that are present in human serum.

In contrast to the results obtained with human serum, the apparent affinity of kIGF-II for IGFBPs in tammar wallaby serum was no different from that of hIGF-II. The apparent affinity of both kIGF-II and hIGF-II for the IGFBPs in wallaby serum, however, appears to be lower than their affinity for IGFBPs present in human serum. This suggests that there may be differences in the number and ratios of the circulating IGFBPs present in the tammar wallaby, or alternatively there may be structural differences between the wallaby and human IGFBPs. It has previously been shown that the IGFBPs in tammar wallaby serum are similar in apparent size and circulating forms to those found in eutherian mammals (Carr et al. 1995). Furthermore, Northern analysis of total liver RNA from wallabies indicated that transcripts for IGFBP-1, -2 and -4 are present in this species. However, the extent of the homology between wallaby IGFBPs and mammalian IGFBPs is not known.

In this study it was revealed that kIGF-II shares structural homology with both non-mammalian and mammalian IGF-IIs. However, kIGF-II contains a tripeptide insertion in the $\mathrm{C}$ domain that is also found in a hIGF-II variant, $\left[\mathrm{Ser}^{29}\right]$-hIGF-II. Characterisation of chicken, human, kangaroo and $\left[\mathrm{Ser}^{29}\right]$-hIGF-II in a number of in vitro assays revealed that these IGF-IIs are also functionally similar. The finding that the major form of circulating IGF-II in the kangaroo is structurally and functionally similar to a minor IGF-II variant in humans is intriguing. Indeed, it is plausible that the differences in 
IGF-II structure in eutherians, metatherians and nonmammalians arose due to a changing role for IGF-II during mammalian development. Hence, it will be interesting to determine if this is in some way linked to the changing role of the CI-MPR, as an IGF-II receptor, in eutherians.

\section{Acknowledgements}

The authors gratefully acknowledge Dr Morey Slodki for generously providing Hansenula holstii phosphomannan, Dr Christine Lüthi for the recombinant [ $\left.\mathrm{Ser}^{29}\right]-$ hIGF-II, Dr Stephen Wilcox for the partial cDNA sequence of wallaby IGF-II and Dr K Nishikawa for the anti-rat IGF-II antibody. We also wish to thank Mr Doug Evans for giving up his time to help us collect kangaroo blood, Professor Russell Baudinette and Ms Jayne Skinner for the tammar wallaby blood, Mr Larry Hick (Wollongong University) for the mass spectrometry analysis and Mr Daryll Lanthois (Agpro Abattoir) for providing the bovine liver. We are also grateful to Dr Andrew Dunbar for his assistance with the RT-PCR and Dr F John Ballard for helpful discussions.

\section{References}

Ballard FJ, Read LC, Francis GL, Bagley CJ \& Wallace JC 1986 Binding properties and biological potencies of insulin-like growth factors in L6 myoblasts. Biochemical Journal 233 223-230.

Brissenden J, Ullrich A \& Francke U 1984 Human chromosomal mapping of genes for insulin-like growth factors I and II and epidermal growth factor. Nature 310 781-784.

Burgisser DM, Roth BV, Giger R, Lüthi C, Weigl S, Zarn J \& Humbel RE 1991 Mutants of human insulin-like growth factor II with altered affinities for the type 1 and type 2 insulin-like growth factor receptor. Journal of Biological Chemistry 266 1029-1033.

Canfield WM \& Kornfeld S 1989 The chicken liver cationindependent mannose 6-phosphate receptor lacks the high affinity binding site for insulin-like growth factor-II. Journal of Biological Chemistry 264 7100-7103.

Carr JM, Owens JA, Baudinette RV \& Wallace JC 1995 Characterization of insulin-like growth factor binding proteins (IGFBPs) in the tammar wallaby, Macropus engenii. General and Comparative Endocrinology 99 50-59.

Clairmont KB \& Czech MP 1989 Chicken and Xenopus mannose 6-phosphate receptors fail to bind insulin-like growth factor II. Journal of Biological Chemistry 264 16390-16392.

Dahms NM, Brzycki-Wessell MA, Ramanujam KS \& Seetharam B 1993 Characterization of mannose 6-phosphate receptors (MPRs) from opossum liver: opossum cation-independent MPR binds insulin-like growth factor II. Endocrinology 133 440-446.

Daughaday WH \& Kapadia M 1989 Significance of abnormal serum binding of insulin-like growth factor II in the development of hypoglycaemia in patients with non-islet-cell tumours. Proceedings of the National Academy of Sciences of the USA 86 6778-6782.

Daughaday WH, Emanuele MA, Brooks MH, Barbato AL, Kapadia M \& Rotwein P 1988 Synthesis and secretion of insulin-like growth factor II by a leiomyosarcoma with associated hypoglycaemia. New England Journal of Medicine 319 1434-1440.

De Ceuninck F, Poiraudeau S, Pagano M, Tsagris L, Blanchard O, Willeput J \& Corvol M 1995a Inhibition of chondrocyte cathepsin
$\mathrm{B}$ and $\mathrm{L}$ activities by insulin-like growth factor-II (IGF-II) and its $\mathrm{Ser}^{29}$ variant in vitro: possible role of the mannose 6-phosphate/ IGF-II receptor. Molecular and Cellular Endocrinology 113 205-213.

De Ceuninck F, Willeput J \& Corvol M 1995b Purification and characterization of insulin-like growth factor II (IGF-II) and an IGF-II variant from human placenta. Journal of Chromatography $B$ $666203-214$.

DeChiara TM, Efstraiadis A \& Robertson EJ 1990 A growthdeficiency phenotype in heterozygous mice carrying an insulin-like growth factor II gene disrupted by targeting. Nature 345 78-80.

Duguay SJ, Chan SJ, Mommsen TP \& Steiner DF 1995 Divergence of insulin-like growth factors I and II in the elasmobranch Squalus acanthias. FEBS Letters 371 69-72.

Duguay SJ, Lai-Zhang J, Steiner DF, Funkenstein B \& Chan SJ 1996 Developmental and tissue-regulated expression of IGF-I and IGF-II mRNAs in Sparus aurata. Journal of Molecular Endocrinology 16 123-132.

Dull TJ, Gray A, Hayflick JS \& Ulrich A 1984 Insulin-like growth factor-II precursor gene organisation in relation to insulin gene family. Nature $310777-781$.

Francis GL, Owens PC, McNeil KA, Wallace JC \& Ballard FJ 1989 Purification, amino acid sequences and assay cross-reactivities of porcine insulin-like growth factor- I and -II. Journal of Endocrinology 122 681-687.

Gowan LK, Hampton B, Hill DJ, Schlueter RJ \& Perdue JF 1987 Purification and characterization of a unique high molecular weight form of insulin-like growth factor II. Endocrinology 121 449-458.

Hampton B, Burgess WH, Marshak DR, Cullen KJ \& Perdue JF 1989 Purification and characterization of an insulin-like growth factor II variant from human plasma. Journal of Biological Chemistry $26419155-19160$.

Han VKM, Bassett N, Walton J \& Challis JRG 1996 The expression of insulin-like growth factor (IGF) and IGF-binding protein (IGFBP) genes in the human placenta and membranes: evidence for IGF-IGFBP interactions at the feto-maternal interface. Journal of Clinical Endocrinology and Metabolism 81 2680-2693.

Haselbacher G \& Humbel RE 1982 Evidence for two species of insulin-like growth factor II (IGF II and 'big' IGF II) in human spinal fluid. Endocrinology 110 1822-1824.

Humbel RE 1990 Insulin-like growth factors I and II. European Journal of Biochemistry 190 445-462.

Jansen M, van Schaik FMA, van Tol H, Van den Brande JL \& Sussenbach JS 1985 Nucleotide sequences of cDNAs encoding precursors of human insulin-like growth factor II (IGF-II) and an IGF-II variant. FEBS Letters 179 243-246.

Kallincos NC, Wallace JC, Francis GL \& Ballard FJ 1990 Chemical and biological characterization of chicken insulin-like growth factor-II. Journal of Endocrinology 124 89-97.

Kita K, Tomas FM, Owens PC, Knowles SE, Forbes BE, Upton Z, Hughes R \& Ballard FJ 1996 Influence of nutrition on hepatic IGF-I mRNA levels and plasma concentrations of IGF-I and IGF-II in meat-type chickens. Journal of Endocrinology 149 181-190.

Louvi A, Accili D \& Efstratiadis A 1997 Growth-promoting interaction of IGF-II with the insulin receptor during mouse embryonic development. Developmental Biology 189 33-48.

Lüthi C, Roth BV \& Humbel RE 1992 Mutants of human insulinlike growth factor II (IGF-II). Expression and characterization of truncated IGF-II and two naturally occurring variants. European Journal of Biochemistry 205 483-490.

Renfree MB 1993 Diapause, pregnancy and parturition in Australian marsupials. Journal of Experimental Zoology 266 450-462.

Renfree MB 1995 Monotreme and marsupial reproduction. Reproduction, Fertilisation and Development 7 1003-1020.

Reynolds TS, Stevenson KR \& Wathes DC 1997 Pregnancy-specific alterations in the expression of the insulin-like growth factor system during early placental development in the ewe. Endocrinology 138 886-897. 
Rinderknecht E \& Humbel RE 1978 Primary structure of human insulin-like growth factor II. FEBS Letters 89 283-286.

Sakano K, Enjoh T, Numata F, Fujiwara H, Marumoto Y, Higashihashi N, Sato Y, Perdue JF \& Fujita-Yamaguchi Y 1991 The design, expression and characterization of human insulin-like growth factor II (IGF II) mutants specific for either the IGF-II/ cation-independent mannose 6-phosphate receptor or IGF-I receptor. Journal of Biological Chemistry 266 20626-20635.

Scott CD \& Baxter RC 1987 Purification and immunological characterization of the rat liver insulin-like growth factor-II receptor. Endocrinology 120 1-9.

Straczek J, Heulin MH, Chenut AM, Lasbennes A, Geschier C, Belleville F \& Nabet P 1990 Purification and characterization of three molecular forms of insulin-like growth factor II from human Cohn paste IV. Journal of Chromatography 532 237-248.

Szabo L, Mottershead DG, Ballard FJ \& Wallace JC 1988 The bovine insulin-like growth factor (IGF) binding protein purified from conditioned medium requires the $\mathrm{N}$-terminal tripeptide in IGF-I for binding. Biochemical and Biophysical Research Communications 151 207-214.

Tricoli JV, Rall LB, Scott J, Bell GI \& Shows TB 1984 Localization of insulin-like growth factor genes to human chromosomes 11 and 12 Nature 310 784-786.
Upton Z, Francis GL, Kita K, Wallace JC \& Ballard FJ 1995 Production and characterization of recombinant chicken insulin-like growth factor-II from Escherichia coli. Journal of Molecular Endocrinology 14 79-90.

Van den Brande JL, Hoogerbrugge CM, Beyreuther K, Roepstorff P, Jansen J \& van Buul-Offers SC 1990 Isolation and partial characterization of IGF-like peptides from Cohn fraction IV of human plasma. Acta Endocrinologica 122 683-695.

Wang Z-Q, Fung MR, Barlow DP \& Wagner EF 1994 Regulation of embryonic growth and lysosomal targeting by the imprinted Igf2/Mpr gene. Nature 372 464-467.

Yandell CA, Francis GL, Wheldrake JF \& Upton Z 1998 Purification, amino acid sequence and characterization of kangaroo IGF-I. Journal of Endocrinology 156 195-204.

Zumstein PP, Lüthi C \& Humbel RE 1985 Amino acid sequence of a variant pro-form of insulin-like growth factor-II. Proceedings of the National Academy of Sciences of the USA 82 3169-3172.

Received 9 November 1998

Accepted 29 January 1999 
